Jurnal Proffesional FIS UNIVED Vol.1 No.1 Februari 2014

\title{
APLIKASI STRATEGI KOMUNIKASI PEMASARAN SURAT KABAR HARIAN RAKYAT BENGKULU DALAM MENJARING PENGIKLAN
}

\author{
Oleh : \\ Vethy Octaviani \\ Dosen Tetap Prodi Ilmu Komunikasi Fakultas Ilmu Sosial UNIVED Bengkulu
}

\begin{abstract}
The picture of reality formed by the mass media was expected to underlie the response and attitude of the public towards various social conditions. It will indirectly affect the domestic firms, because in any case, they must be prepared to compete with other similar companies as well as the need to have courage in the face of competition from multinational companies that operate and are located in various areas. In this study the researcher used theories derived from sources that can be used as a reference. Data were collected by using interview techniques and data analysis. From the research, it's known that the application of marketing communications strategy in Harian Rakyat Bengkulu was to attract advertising. The applied strategies was chosen by the needs, it means that the application of the strategy used is not too theoretical cultivated and made as simple as possible and inspired by the vision of the company. Basically every company (in this case Harian Rakyat Bengkulu) needed to apply marketing communication strategy in the company's vision and mission more effectively. Without the application of marketing communication strategy, the company most likely would not run well.
\end{abstract}

Keywords: company, marketing communications strategy, advertiser

\section{PENDAHULUAN}

Peranan media dalam kehidupan sosial bukan sekedar sarana atau pelepas ketegangan dan hiburan. Isi dan informasi yang disajikan mempunyai peranan yang sangat penting dalam proses sosial. Menurut Peter Berger isi media massa merupakan konsumsi otak bagi khalayaknya, sehingga hal yang ada dalam media massa akan mempengaruhi persepsi mereka (Subiakto, 2001:11).

Gambaran tentang realitas yang ingin dibentuk oleh media massa diharapkan bisa mendasari respon dan sikap khalayak terhadap berbagai kondisi sosial. Hal tersebut secara tidak langsung akan berpengaruh terhadap perusahaan- perusahaan domestik, karena dalam kondisi apapun harus siap bersaing dengan perusahaan lain yang sejenis serta harus memiliki keberanian dalam menghadapi persaingan dengan perusahaan multinasional yang beroperasi dan berlokasi diberbagai bidang.

Surat Kabar Harian Rakyat Bengkulu sebagai salah satu suratkabar di Bengkulu tentunya memiliki banyak persaingan dari organisasi bisnis yang sejenis. Dari sisi lain, juga harus berusaha untuk memenuhi tuntutan atas berita nasional maupun berita lokal/daerah. Seringkali tolak ukur berdasarkan pada bagaimana strategi pemasaran menjalankan fungsi pertukaran atau jual beli, serta bagaimana menerapkan komunikasi yang efektif bagi khalayak. 
Memang tidak bisa dipungkiri bahwa tanpa adanya komunikasi (antara produsen dan konsumen) apapun bentuk suatu usaha tidak akan dikenal oleh masyarakat. Demikian hanya dengan Surat Kabar Rakyat Bengkulu yang notabene sebagai salah satu perusahaan penerbitan yang telah memasuki fase persaingan yang cukup tinggi dengan perusahaan lain, hendaknya mampu melakukan terobosan-terobosan baru untuk memenangkan persaingan.

Disisi lain fenomenal yang menarik adalah munculnya berbagai iklan yang telah mewarnai jembatan-jembatan atau halamanhalaman yang ada dalam surat kabar. Perkembangan iklan selanjutnya di Surat Kabar Rakyat Bengkulu dari waktu ke waktu semakin pesat. Hal inilah yang menarik untuk dijadikan wacana karena ternyata iklan sangat membantu perusahaan dalam mendukung usahanya, serta sebagai salah satu sumber pendapatan yang tidak lepas dari sasaran utamanya. Tujuan penelitian ini adalah untuk mengetahui strategi komunikasi pemasaran Surat Kabar Rakyat Bengkulu dalam menjaring pengiklan dan sebagai bahan perbandingan antara teori yang diperoleh dibangku kuliah dengan kenyataan di lapangan.

\section{METODE PENELITIAN}

Dalam penelitian ini peneliti menggunakan teori-teori yang diambil dari sumber yang dapat dijadikan acuan, kegiatan studi pustaka merupakan upaya pengumpulan data dari teori melalui bukubuku, surat kabar, majalah serta sumber informasi non manusia sebagai penunjang penelitian (seperti dokumen, agenda, hasil penelitian, rekaman atau catatan, kliping) dan kegiatan-kegiatan lainnya. Selain dari mencari sumber-sumber teori yang ada peneliti juga melakukan kegiatan observasi yaitu teknik pengumpulan data diperoleh serta dilaksanakan dengan cara mengamati bagaimana strategi yang dilakukan Surat Kabar Rakyat Bengkulu. Pengamatan dilakukan secara langsung terhadap objek penelitian yaitu Surat Kabar Rakyat Bengkulu dan segala kegiatan yang mengacu pada strategi komunikasi pemasaran dalam menjaring pengiklan, Selanjutnya proses tanya jawab secara langsung dengan pihak yang berwenang, analisa yang dilakukan adalah pengolahan data kualitatif yaitu prosedur penelitian yang menghasilkan data deskriptif berupa kata-kata tertulis atau lisan dari orang-orang yang dapat diamati (Bogdan dan Taylor, 1975:3).

\section{HASIL PENELITIAN DAN PEMBAHASAN}

\section{Aplikasi Strategi Komunikasi Pemasaran Surat Kabar Harian Surat Kabar Rakyat Bengkulu Dalam Menjaring periklanan.}

Hampir dipastikan bahwa setiap media bergabung pada pemasukan dari iklan, bahkan sebagian besar untuk biaya operasional. Pada umumnya perusahaan penerbitan seperti surat kabar sangat menghandalkan iklan untuk menutup sebagian dari biaya produksi dan menambah keuntungan. Oleh karena itu, tanpa adanya aplikasi strategi komunikasi pemasaran, apapun jenis bentuk usaha tidak akan dikenal oleh masyarakat. Begitu juga dengan Surat Kabar Rakyat Bengkulu yang dapat dikategorikan sebagai "produk baru" dan harus berhadapan dengan persaingan mendapatkan pembaca dan pengiklan, maka banyak aplikasi strategi komunikasi pemasaran dalam menunjang usahanya. Aplikasi strategi yang digunakan disesuaikan dengan kebutuhan yang ada, artinya bahwa aplikasi strategi yang digunakan diusahakan tidak terlalu teoritis dan dibuat sesederhana mungkin serta dijiwai oleh visi perusahaan. 
Berikut akan dibahas langkah-langkah Surat Kabar Rakyat Bengkulu dalam menjaring pengiklan, dengan menggunakan teori yang digunakan oleh Frank Jenkins yaitu melalui 7 (tujuh) item strategi antara lain :

\section{Periklanan}

Periklanan merupakan salah satu bentuk khusus komunikasi yang dilakukan oleh Surat Kabar Rakyat Bengkulu dalam rangka untuk mempengaruhi khalayak agar berperilaku sedemikian rupa sesuai dengan strategi komunikasi pemasaran, yang mana strategi ini merupakan cara yang tepat untuk memberikan hasil produk/jasa kepada calon pengiklan yang sama sekali belum mereka dikenal. Surat Kabar Rakyat Bengkulu menganggap bahwa iklan merupakan sarana promosi yang dirasakan promosi yang dirasakan paling efektif dan efesien, karena dapat menjangkau masyarakat luas dan serentak. Iklan tersebut dilakukan dengan menggunakan media cetak dan media elektronik. Surat Kabar Rakyat Bengkulu melakukan pengkategorian iklan yaitu (a) Iklan lini atas, yaitu jenis iklan yang mengharuskan pembayaran komisi kepada biro iklan (Jefkins, 1996:28). Ini merupakan iklan yang diprioritaskan atau yang diunggulkan Surat Kabar Rakyat Bengkulu dalam usahanya untuk menjaring pengiklan. Aplikasi yang dilakukan oleh Surat Kabar Rakyat Bengkulu dalam usahanya untuk menjaring pengiklan. Aplikasi yang dilakukan oleh Surat Kabar Rakyat Bengkulu untuk mewujudkan strategi ini antara lain, (b) Iklan lini bawah, yaitu jenisjenis iklan yang tidak mengharuskan adanya komisi (Jefkins, 1996:29). Media yang digunakan antara lain dengan spanduk, outdoor, dan stiker. Beberapa aktifitas yang dilakukan oleh Surat Kabar Rakyat Bengkulu, yaitu menjalin kerjasama dengan pihak lain, seperti menggelar kontes musik dan menyanyi tembang kenangan yang mana harian ini mencantumkan logonya pada brosur pendaftaran. Logo terutama dipasang sebagai simbol pemerintah daerah untuk memberi ciri khas Surat Kabar Rakyat Bengkulu. Hal tersebut cukup relatife mengingatkan secara langsung peserta melakukan pendaftaran di kantor Surat Kabar Rakyat Bengkulu. Tujuan kegiatan tersebut adalah untuk menginformasikan keberadaan Surat Kabar Rakyat Bengkulu sebagai Koran lokal, sekaligus salah satu cara agar bisa mengundang perhatian orang banyak yang menantinya akan berdampak positif pada citra merek, sehingga diharapkan dapat meningkatkan oplah penjualan dan omset iklan. Media lain yang digunakan yaitu berupa spanduk yang dipasang disisi-sisi jalan raya. Media ini merupakan yang murah biaya pembuatan dan pemasangan. Salah satu contoh dengan spanduk yang bisa ditemui adalah di depan kantor SKH Rakyat Bengkulu

\section{Stiker}

Merupakan salah satu bentuk media yang digunakan dalam strategi-strategistrategi pemasaran. Bentuknya yaitu berupa potongan-potongan kertas yang dapat ditempel di tempat-tempat tertentu. Cara pemasanganya yaitu dengan menarik dan menggeraikan lembaran tersebut. Alasan penggunaan stiker ini sebagai hiasan, media ini juga bisa menjadi identitas sekaligus sebagai wahana informasi. Pembagian stiker ini dilakukan oleh panitia kepada pengunjung pada acara-acara tertentu, seperti seminar. Stiker ini memuat nama/jenis kegiatan serta nama Surat Kabar Rakyat Bengkulu. Hal ini merupakan salah satu konpensasi dari pihak penyelenggara acara untuk mencantumkan nama 'Surat Kabar Rakyat Bengkulu', sedangkan pihak Surat Kabar Rakyat Bengkulu merelease/meliput acara tersebut. 


\section{Outdoor}

Yaitu media yang berupa papan besar bergambar (billboard) yang dipasang di tempat strategi atau pada tempat-tempat terbuka atau tempat-tempat yang mudah dilihat oleh masyarakat. Iklan luar tersebut dilengkapi dengan efek mencolok. Fungsi utama sarana ini adalah sebagai iklan sekaligus untuk mengingatkan serta sebagai media sekunder untuk mendukung strategi komunikasi pemasaran. Hal tersebut menunjukakan bahwa Surat Kabar Rakyat Bengkulu cukup memperhatikan media yang digunakan sehingga tidak alasan-alasan dalam memilih jenis media. Pemilihan media yang sesuai, dengan dapat mempengaruhi karekteristik publiknya sehingga media dapat digunakan secara efektif dan efesien.

Pemilihan media di atas diharapkan dapat mempengaruhi kesadaran konsumen melalui imanjinasi yang terbentuk setekah calon pengiklanan membaca, mengamati dan menganalisis isi pesan yang disampaikan dengan kata-kata yang bersifat membujuk yang tertera di dalamnya secara langsung. Oleh karena itu, diharapkan khalayak dapat memahami pesan yang disampaikan kemudian mereka akan mencobanya dengan cara memasang iklan di Surat Kabar Rakyat Bengkulu.

Alasan penggunaan aplikasi strategi periklanan sebagai usaha untuk menjaring pengiklan didasarkan pada: Periklanan diharapkan mampu mengubah atau mempengaruhi sikap khalayak untuk membeli produk (baik iklan maupun koran), bahwa periklanan tidak hanya berkaitan dengan sekadar memberikan informasi mengenai produk atau jasa, tetapi periklanan harus mampu menciptakan rasa tertarik dan perhatian khalayak, sehingga mereka dengan senang hati terdorong untuk melakukan suatu tindakan yang sesuai dengan keinginan perusahaan. Tindakan tersebut antara lain, adanya keinginan dari khalayak untuk meminta keterangan lebih jauh mengenai suatu produk, atau sekedar mengingatkan suatu produk ke dalam benaknya (baik iklan maupun koran). Oleh karena itu jelas bahwa dengan penggunaan iklan dibuat secara bervariasi akan menimbulkan reaksi dari masyarakat yang pada akhirnya akan menimbulkan keputusan yaitu berupa pembelian.

Surat Kabar Rakyat Bengkulu sebagai sumber pesan dalam komunikasikan produk unggulan kepada masyarakat yaitu dengan menggunakan media iklan. Hal ini sesuai dengan pendapat Kotler (1999:242) bahwa media yang digunakan untuk beriklan dapat berbentuk media cetak, elektronik, bookler, brosur, poster dan media luar ruangan. Merupakan suatu langkah atau tindakan yang sangat, yang mana Surat Kabar Rakyat Bengkulu selalu berusaha untuk melakukan yang terbaik sehingga dirinya tidak akan ketinggalan dengan persaingan pasar yang semakin kompetitif.

Berbagai jenis media iklan yang digunakan, Surat Kabar Rakyat Bengkulu ternyata lebih mengandalkan iklan radio daripada media yang lain. Hal ini seperti yang telah dijelaskan sebelumnya bahwa radio merupakan media yang dilakukan lewat suara dan memungkinkan penggunaan kata-kata yang dramatis, lagu-lagu khusus yang mudah diingat.

Dari uraian diatas Surat Kabar Rakyat Bengkulu telah menunjukkan keberadaannya sebagai surat kabar lokal sekaligus memberikan keyakinan dan membujuk masyarakat untuk menggunakan produk/jasa baik iklan maupun Koran. Disamping itu dari waktu ke waktu perkembangan radio semakin gencar, maka Surat Kabar Rakyat Bengkulu sebagai pihak yang memasang iklan harus lebih selektif dalam memilih radio. Artinya dengan semakin banyaknya jumlah stasiun radio, maka akan mengakibatkan pemirsa atau pendengar lebih teliti dalam memilih radio (terutama 
dari segi acara). Misalnya mensponsori kuis dengan memberikan hadiah yang besar, serta tidak lupa utnuk menentukan waktu siar yang sesuai dengan jenis produk serta sasaran yang menjadi target. Ada satu hal yang perlu diperhatikan Surat Kabar Rakyat Bengkulu intensitas pemasangan pada berbagai media tersebut. Karena seperti penggunaan iklan melalui radio terkadang harus menuntut atau khalayak untuk selalu fokus pada acara tertentu, sehingga dapat mengakibatkan kejenuhan. Oleh karena itu intensitas penggunaan media radio sebagai penyampaian iklan Surat Kabar Rakyat Bengkulu perlu ditingkatkan. Intensitas ini menjadi sangat penting yang dikatakan Temporal (2000), meskipun sedang resensi sebuah perusahaan harus beriklan untuk menampilkan merek kepada dunia luar. Masyarakat harus terus menerus disadarkan akan ekstensitas perusahaan tersebut. Begitu pula dengan Surat Kabar Rakyat Bengkulu.

Penyadaran terdapat masyarakat ini dapat dilakukan dengan penayangan iklan yang bersifat informatif. Selain itu untuk dapat membujuk khalayak sasaran, sebuah iklan haruslah menarik, mampu memfokuskan perhatian serta merangsang klien untuk memberikan sikap positif pada produk yang disampaikan. Untuk realisasinya, hendaknya semua tim Surat Kabar Rakyat Bengkulu memiliki wawasan serta pengetahuan yang besar terhadap produknya. Kemudian dari pengamatan penulis bahwa sebenarnya dalam pengguna iklan lini bahwa seperti produk, outdoor, dapat mengurangi perhatian konsumenkonsumen untuk mengingat-ingat pesan yang ada, sebab mereka hanya melihat iklan tersebut sambil berjalan selain sangat rentan terhadap cuaca seperti panas, hujan, sehingga dimungkinkan dapat merusak kualitas tampilannya.

Berkaitan dengan masalah tersebut, Frank Jenkins (1996;130) memberikan penjelasan yang berkaitan dengan kelemahan penggunaan outdoor, yaitu Ketidak mampunya memuat banyak iklan sekaligus, Rentan terhadap vandalism atau cuaca, Kurangnya konsentrasi penonton untuk mengingat pesan-pesan poster (outdoor) karena mereka melihat iklan tersebut sambil lewat. Oleh karena itu Surat Kabar Rakyat Bengkulu harus memperhatikan media yang akan digunakan, sehingga tujuan yang diinginkan dapat tercapai, yaitu : (1) Penjualan langsung/tatap muka, penjualan langsung merupakan strategi komunikasi yang dapat mendekati khalayak secara langsung, sehingga pesan yang disampaikan dapat diterima dengan baik.

Bagi Surat Kabar Rakyat Bengkulu komunikasi yang dilakukan secara langsung dapat menyadarkan khalayak dan memberikan informasi tentang suatu barang, ide/jasa, sehingga diharapkan khalayak dan memberikan informasi tentang suatu barang, ide/jasa, sehingga diharapkan khalayak menggunakan barang/jasa serta tertarik untuk memasang iklan di Surat Kabar Rakyat Bengkulu. Untuk aktivitas sebagai realisasi penjualan langsung adalah komunikasi atau percakapan yang dilakukan antara $A E$ (Accont Executive) dengan mengiklankan yaitu dengan melakukan komunikasi secara pribadi atau dengan mengiklankan yaitu dengan menggunakan pesawat telepon. Kegiatan penjualan langsung tersebut dilakukan ditempattempat tertentu, seperti ketika Surat Kabar Rakyat Bengkulu melakukan seminar, namun terkadang penjualan langsung dilakukan di kantor Surat Kabar Rakyat Bengkulu. Telemarketing juga dilakukan oleh Surat Kabar Rakyat Bengkulu yakni dengan menelepon pelanggan/pengiklan yang menjadi konsumen tetap perusahaan.

Untuk mengetahui daftar nama-nama calon pengiklan dan nomor telepon, Surat Kabar Rakyat Bengkulu telah memiliki referensinya, baik dari kalangan perusahaan, 
pengusaha maupun pembaca yang ada di Bengkulu. Upaya untuk menyakinkan calon pengiklanan, seorang $\mathrm{AE}$ harus mempunyai kecakapan diplomatis serta memiliki pengetahuan periklanan yang luas dan mampu bekerja sama sehingga bisa mengarahkan setiap pekerjaannya untuk kepentingan klien. Hal ini dikarenakan seorang AE merupakan pihak yang terkait secara langsung dengan klien sehingga diharapkan mampu memberikan saran-saran untuk klien yang ditangani dan mempelajari tuntutan yang dikehendaki klien terhadap iklan. Alasan penggunaan strategi penjualan langsung antara lain dapat menjual produk secara langsung kepada konsumen, baik melalui percakapan atau komunikasi antara produsen dengan konsumen. Hal ini diharapkan dapat menjelaskan mengenai berbagai produk yang dijual (baik iklan maupun koran) kepada konsumen sekaligus dapat memahami keinginan serta kebutuhan konsumen. Di samping itu dengan mengaplikasikan strategi ini, maka tanggapan-tanggapan konsumen dapat diketahui kemudian dikumpulkan, misalnya dengan memberikan nomor telepon balasan.

Berbagai uraian di atas jelas bahwa pengaplikasian strategis penjualan langsung yang dilakukan oleh Surat Kabar Rakyat Bengkulu melalui komunikasi tatap muka atau dengan menggunakan pesawat telepon, menunjukkan keseriusan dalam menjaring pengiklan. Aplikasi strategis ini diharapkan mampu mendapatkan tanggapan dari klien secara langsung. Namun dalam menentukan calon pengiklan yang hendak dituju, Surat Kabar Rakyat Bengkulu tentu saja tidak asal-asalan, sehingga ia lebih selektif, kirakira konsumen seperti apa yang paling potensial untuk dijadikan sebagai khalayak yang menjadi sasaran atau target penjualan.

Langkah tersebut dinilai cukup berhasil, hal ini terlihat dengan semakin banyaknya pengiklan yang bergabung dengan perusahaan. Akan tetapi penjualan langsung ini akan lebih efektif apabila dikombinasi dengan komponen lain dari promotion mix seperti PR (Public Relations) maupun sales promotions (Belch, 1998:442). Kombinasi tersebut dapat dilakukan Surat Kabar Rakyat Bengkulu dengan memberikan nomor telepon yang dimiliki oleh Surat Kabar Rakyat Bengkulu sehingga konsumen dapat memberikan respon yaitu berupa keputusan untuk membeli. Pensponsoran merupakan pemberian dukungan dalam suatu kegiatan untuk memperoleh keuntungan-keuntungan di bidang strategi pemasaran salain itu pensponsoran juga merupakan bentuk inventasi yang dilakukan oleh pihak sponsor untuk memperoleh hal-hal yang positif demi meningkatkan usahanya. Surat Kabar Rakyat Bengkulu menganggap bahwa pensposoran dapat merangsang konsumen untuk menggunakan produknya (baik iklan maupun koran), serta dapat mengakrapkan nama Surat Kabar Rakyat Bengkulu yang pada akhirnya dapat memperkuat namanya kedalam benak konsumen.

Dalam melakukan kerjasama atau pensponsoran kepada pihak-pihak lain. Surat Kabar Rakyat Bengkulu berusaha untuk terbuka, dalam arti bahwa kegiatan ini dilakukan tanpa memilah-milah dengan pihak mana Surat Kabar Rakyat Bengkulu menjalin kerjasama/pensponsoran, selama kegiatan tersebut sifatnya mendukung program pemasaran. Berbagai kegiatan di atas dapat memberikan kesempatan kepada pihak sponsor (Surat Kabar Rakyat Bengkulu) untuk merangsang kalimat iklan pada saat-saat tertentu, baik di awal, ditengah maupun penghujung suatu acara. Akan tetapi Surat Kabar Rakyat Bengkulu (sebagai pihak sponsor) tidak ikut terlibat secara langsung dalam pembuatan acara dan produknya pun tidak dipakai sebagai materi acara. Penggunaan kegiatan di atas sebagai usaha untuk menjaring pengiklan, karena event-event tersebut merupakan saah satu 
acara yang banyak diminati oleh masyarakat luas. Adapun alasan yang hendak dicapai melalui pengaplikasian strategi ini adalah untuk merangsang calon pengiklan pengguna produk/jasa Surat Kabar Rakyat Bengkulu. Surat Kabar Rakyat Bengkulu memanfaatkan strategi ini sebagai salah satu taktik untuk memperoleh pengiklan. Untuk menempatkan posisi sebuah produk/jasa pada segmen tertentu. Seperti yang telah diketahui bahwa Surat Kabar Rakyat Bengkulu menempatkan suatu produk ke dalam segmen pasar tertentu, yaitu kelompok masyarakat menengah ke atas. Oleh karena itu Surat Kabar Rakyat Bengkulu selalu berusaha untuk mensponsori kegiatan yang berkaitan dengan minat kelompok sasaran.

Disamping itu Surat Kabar Rakyat Bengkulu perlu memperhatikan bahwa mayoritas penduduk Bengkulu adalah mahasiswa, sehingga perlu untuk melakukan pensponsoran pada acara-acara yang banyak diminati oleh mereka (mahasiswa), seperti sponsor pendidikan, beasiswa atau penelitian-penelitian. Berbagai jenis kegiatan tersebut diharapkan mampu mempengaruhi diharapkan mampu mempengaruhi konsumen/calon pengiklan, sehingga pada giliranya bisa meningkatkan jumlah pengiklan.

Semua kegiatan pensponsoran di atas tertentu saja membutuhkan riset yang matang sebelum kegiatan di mulai, sehingga nantinya perusahaan mendapatkan keuntungan yang sesuai dengan harapan. Hal ini sesuai dengan pendapat Alan Poscoe Associates (Jefkins, 1996:175-176) antara lain : (a) Audit terhadap kebijakan-kebijakan pensponsoran perusahaan yaitu dengan meneliti kembali mengenai apa saja yang pernah dibiayai atau disponsori oleh perusahaan yang bersangkutan di masa sebelumnya. (b) Penetapan tujuan yaitu dapat mengetahui apa sebenarnya tujuan yang hendak dicapai melalui pensponsoran. (c) Perumusan strategi yaitu dengan mengetahui strategi/metode-metode apa yang sekiranya harus diambil dan untuk maksud apa. (d) Pelaksanaan negoisasinegoisasi dengan pihak ketiga yaitu mencakup perundingan-perundingan dengan berbagai pihak atau asosiasi-asosiasi yang berwenang terhadap subyek pensponsoran. (e) Penyelenggaraan konferensi pers harus dilakukan seawal mungkin untuk mengumumkan pensponsoran guna mendukung tercapainya tujuan pensponsoran. (f) Menghubungi dinas-dinas pemerintahan kota yang terkait, hal ini dilakukan guna mengantisipasi hal-hal yang tidak diinginkan, sehingga apabila suatu kegiatan mengambil tempat-tempat di jalan raya, maka diperlukan pengaturan khusus dengan dinas-dinas kota yang terkait. (g) Penerjemah rancangan, yaitu menuangkan rancangan secara detail mengenai hal-hal yang berkaitan dengan kegiatan pensponsoran. (h) Pengaturan kegiatan di lapangan, hal ini dilakukan agara kegiatan di lapangan dapat berjalan baik dan tertib, sehingga tidak terjadi sesuatu di luar dugaan, seperti keributan, perkelahian dan sebagainya. Biasanya untuk menghindari kejadian tersebut diperlukan pihak-pihak berwenang yang dapat membantu jalannya acara, seperti polisi. (i) Analisis, yaitu analisa jalannya kegiatan dari awal sehingga akhir. Hal ini dilakukan untuk menentukan bagaimana kemungkinan pelaksanaan yang lebih baik di masa yang akan datang.

Berbagai aktivitas yang telah dilakukan, menunjukkan bahwa Surat Kabar Rakyat Bengkulu cukup serius dalam usahanya untuk menjaring pengiklan. Hal ini terbukti dengan adanya pemberian harga khusus dengan sangat hati-hati, untuk menghindari kesan mengenai produk yang kurang berkualitas, yaitu hanya terbatas pada jenis iklan di kolom. Disamping itu pemberian harga khusus dapat dijadikan sebagai pemikat yang dapat ditawarkan 
kepada calon pengiklan. Dalam melaksanakan program promosi Surat Kabar Rakyat Bengkulu juga perlu memperhatikan apakah ini akan selalu berdampak positif bagi kemajuan Surat Kabar Rakyat Bengkulu. Terkadang ada sejumlah konsumen yang tertarik pada produk/jasa tertentu hanya pada saat diadakan promosi penjualan, akibatnya pada waktu yang berlainan berpindah pada produk yang lain yang menawarkan produk dengan harga relatif lebih rendah. Memang strategi promosi penjualan mengandung daya tarik yang cukup besar bagi calon pengiklanan, akan tetapi jika pelaksanaan promosi penjualan mengandung daya tarik yang cukup besar bagi calon pengiklan, akan tetapi jika pelaksanaan promosi tidak sesuai dengan tempatnya, maka hal ini akan berakibat pada rusaknya citra dan produk perusahaan. Salah satu contoh nyata yang penulis jumpai yaitu kecewanya klien akibat tidak dimuatnya iklan karena adanya kesalahan teknis, yang mana sesuai dengan perjanjian iklan tersebut harus ditayangkan. Akan tetapi sebagai konsekuensinya terhadap klien terhadap masalah tersebut, Surat Kabar Rakyat Bengkulu iklan tersebut harus ditanyangkan. Akan tetapi sebagai konsekuensinya terhadap klien terhadap masalah tersebut, Surat Kabar Rakyat Bengkulu memberikan tambahan tayangan iklan secara berturut-turut (sebanyak 2-3 kali tayang).

Dari uraian di atas hendaknya Surat Kabar Rakyat Bengkulu lebih berhati-hati dalam segala tindakan, karena hal ini akan berpengaruh pada citra perusahaan. Karena komunikasi berpangkal dari dalam perusahaan, seandainya kegiatan promosi penjualan tersebut tidak didukung/disetujui oleh manajemen dan tenaga penjualan perusahaan itu sendiri, maka sangat kecil peluangnya diterima pihak lain (Hood,1997).

\section{Tenaga Penjualan}

Perkembangan sistem komunikasi dan distribusi yang semakin maju, menurut perusahaan untuk mengembangkan penjualan produk ke pasar-pasar lain. Begitu juga dengan Surat Kabar Rakyat Bengkulu untuk memenangkan persaingan, perusahaan ini perlu mengangkat agen penjualan untuk membantu mereka dalam menjual produk, baik koran maupun iklan kepada konsumen. Jumlah tenaga penjualan yang dimiliki oleh Surat Kabar Rakyat Bengkulu kini telah mencapai 14 agen yang tersebar di seluruh pelosok kota Bengkulu yaitu Kota Bengkulu, kabupaten Bengkulu Utara, kabupaten Bengkulu Selatan dan lain-lain. Disamping itu Surat Kabar Rakyat Bengkulu sangat memberdayakan tenaga asongan. Namun demikian meskipun keberadaanya tenaga asongan di bawah kendali agen koran, Surat Kabar Rakyat Bengkulu tetap memperhatikan dan memberdayakan tenaga asongan sebagai ujung tombak pemasaran. Sebab peran mereka sangat besar karena melalui tenaga asongan itulah Surat Kabar Rakyat Bengkulu lebih dikenal oleh masyarakat sekaligus dapat membantu meningkatkan oplah koran dan omset iklan. Beberapa agen di atas menjadi tanggung jawab Surat Kabar Rakyat Bengkulu, sedangkan tenaga asongan menjadi tanggung jawab agen.

Dalam mengaplikasikan strategi ini pihak perusahaan dan tenaga penjual dituntut untuk saling bantu-membantu sehingga hubungan kerja diantara keduanya cenderung menjadi lebih akrab. Langkah nyata yang dilakukan oleh Surat Kabar Rakyat Bengkulu yaitu dengan melakukan siasat bagi tenaga penjualan dan tenaga asongan untuk mengenakan rompi yang bertulisan "Surat Kabar Rakyat Bengkulu" dengan tujuan untuk menarik perhatian pembeli. Penggunaan rompi tersebut diharapkan dapat menciptakan identitas perusahaan sekaligus sebagai langkah untuk 
menjaring pengiklan. Alasan penggunaan strategi tenaga penjualan adalah melakukan penjualan dengan bertatap muka antara penjual dan pembeli sekaligus menanamkan Surat Kabar Rakyat Bengkulu di dalam benak pembeli.

Penggunaan tenaga penjualan yang dilakukan oleh Surat Kabar Rakyat Bengkulu merupakan langkah yang tepat, karena melalui tenaga penjualan inilah dapat membantu perusahaan untuk meningkatkan oplah penjualan dan omset iklan. Disamping itu tenaga penjualan dapat berperan sebagai wakil dan perusahaan yang dapat memberikan informasi kepada calon pengiklanan mengenai suatu produk/jasa, karena memiliki andil yang cukup besar di lapangan. Pemakaian rompi kepada tenaga penjualan dan tenaga asongan juga dinilai cukup bagus, karena langkah seperti ini dapat menciptakan identitas perusahaan yang bisa menanamkan nama Surat Kabar Rakyat Bengkulu ke dalam benak konsumen.

\section{Seminar}

Salah satu hal yang mendukung dalam perencanaan kegiatan komunikasi pemasaran adalah dengan melakukan seminar. Seminar merupakan kegiatan yang dilakukan antara perusahaan Surat Kabar Rakyat Bengkulu dengan pihak penyelenggara acara seminar. Bagi Surat Kabar Rakyat Bengkulu ini merupakan sarana yang paling berharga karena dapat menciptakan pertemuan antara penjual dengan calon pengiklan.

Bagi Surat Kabar Rakyat Bengkulu, kegiatan diatas dapat mendatangkan keuntungan yang mana perusahaan diberi hak untuk mencantumkan logonya pada kegiatan tersebut, dan secara tidak langsung dapat menanamkan image kepada khlayak atau peserta seminar tentang bentuk logo Surat Kabar Rakyat Bengkulu. Selain itu kegiatan tersebut kemungkinan besar dapat memberikan daya tarik tersendiri pada khalayak mengenai bentuk rancangan atau logo yang lain dari pada yang lain. Disamping itu, strategi ini dinilai cukup efektif karena ketika acara berlangsung, baik pada waktu awal acara, di tengah-tengah acara maupun di akhir acara, panitia kegiatan menyebutkan pihak-pihak yang mendukung acara tersebut. Aktivitas lain yang dilakukan yaitu dengan menyebarkan stiker-stiker yang berisi tentang nama kegiatan serta nama Surat Kabar Rakyat Bengkulu yang bisanya diberikan secara cuma-cuma oleh panitia kegiatan kepada peserta di tempat berlangsungnya seminar.

Alasan penggunaan strategi tersebut dengan tujuan untuk menanamkan nama Surat Kabar Rakyat Bengkulu ke dalam benak konsumen, sekaligus upaya untuk menjaring pengiklan. Berbagai strategi yang telah dijalankan oleh Surat Kabar Rakyat Bengkulu dinilai cukup baik, hal ini terlihat ketika Surat Kabar Rakyat Bengkulu melakukan kerjasama dengan pihak lain serta adanya konpensasi dari panitia kegiatan untuk mencantumkan nama Surat Kabar Rakyat Bengkulu dalam stiker kemudian disebarkan secara cuma-cuma kepada peserta. Hal ini sebagai langkah yang cukup kreatif yang mana seiring dengan perkembangan dunia bisnis yang semakin kompetitif, Surat Kabar Rakyat Bengkulu juga tidak luput untuk melakukan terobosan-terobosan baru guna memenangkan persaingan.

Beberapa hal yang perlu diperhatikan bahwa penggunaan strategi ini sebenarnya kurang begitu berpengaruh besar, karena pengunjung atau peserta bisaanya lebih fokus pada acara yang sedang berlangsung (meskipun tidak secara keseluruhan), sehingga mereka kurang begitu memperhatikan logo/pihak-pihak yang ikut terlibat dalam penyelenggaraan acara seminar (dalam hal ini Surat Kabar Rakyat Bengkulu). Oleh karena itu, Surat Kabar Rakyat Bengkulu perlu lebih berhati-hati dan selektif dalam penentuan strategi 
komunikasi pemasaran dan pengaplikasiannya, sebab apapun bentuk kegiatan yang dilakukan tentu membutuhkan persiapan yang lebih matang.

Disamping ketujuh item strategis komunikasi pemasaran dan aplikasinya yang dilakukan, Surat Kabar Rakyat Bengkulu juga melakukan penetrasi pasar sebagai salah satu strategi dalam rangka menjaring pengiklanan. Alasan penggunaan dan pengaplikasian strategi ini adalah untuk melihat sampai sejauh mana keberhasilan suatu produk di pasaran. Berbagai aktivitas sebagai realisasi dari strategi ini adalah pensponsoran dan kegiatan lainnya. Pada saat acara tersebut Surat Kabar Rakyat Bengkulu melakukan pendekatan kepada calon pengiklan untuk mengetahui seberapa besar respon publik terhadap perusahaan, baik dari segi iklan maupun korannya. Sebab seperti yang telah dijelaskan sebelumnya bahwa terdapat ambiguitas di dalam masyarakat antara Jawa Pos dengan Surat Kabar Rakyat Bengkulu dan menganggap Surat Kabar Rakyat Bengkulu sebagai koran pendatang. Padahal Surat Kabar Rakyat Bengkulu tergabung dalam Jawa Pos group.

Berbagai langkah yang dilakukan yakni dengan melakukan komunikasi secara langsung/tatap muka yang mana pada kesempatan tersebut Surat Kabar Rakyat Bengkulu melakukan tanya jawab. Tanya jawab sifatnya tidak langsung sehingga masyarakat tidak mengetahui bahwa pada waktu itu Surat Kabar Rakyat Bengkulu sedang melakukan pendekatan untuk mengetahui respon publik terhadap perusahaan.

Dengan mengaplikasikan beberapa strategi komunikasi pemasaran, mengindikasikan adanya kesadaran Surat Kabar Rakyat Bengkulu untuk melakukan berbagai aktivasi dalam meningkatkan perkembangan Surat Kabar Rakyat Bengkulu.
Faktor Pendukung Aplikasi Strategi komunikasi Pemasaran Surat Kabar Rakyat Bengkulu Dalam Menjaring Pengiklan

AE merupakan faktor yang penting dalam membantu aplikasi strategi komunikasi pemasaran perusahaan karena keberadaannya berkaitan langsung dengan klien sehingga dituntut memiliki kemampuan untuk mengetahui klien. Servis berita yang diberikan kepada pengiklan.

Pelayanan berita yang dimaksudkan agar terjadi kerjasama secara berkesinambungan antara produsen dengan produsen. Strategi ini sebenarnya membawa keuntungan bagi kedua bela pihak. Satu sisi dapat membantu klien dalam mengembangkan usahanya melalui produk yang dipercayakan kepada Surat Kabar Rakyat Bengkulu dan dapat berkesinambungan dan dilaksanakan berdasarkan suatu jadwal yang menunjukkan peran satu atau berbagai media) periklanan. Sementara itu disisi lain dapat merangsang klien agar menggunakan jasa Surat Kabar Rakyat Bengkulu. Hal inilah yang dapat membantu perusahaan untuk meningkatkan omset iklan.

Faktor Penghambat Pelaksanaan Aplikasi Strategi Komunikasi Pemasaran Surat Kabar Rakyat Bengkulu Dalam Menjaring Pengiklan

Adapun faktor penghambat diantaranya; (1) Surat Kabar Rakyat Bengkulu termasuk perusahaan yang usianya masih muda sehingga belum banyak dikenal oleh masyarakat. (2) Pangsa pasarnya belum terlalu besar karena koran di Bengkulu sangat konpetitif (3) Persaingan yang sangat ketat dengan perusahaan lain yang sejenis, seperti Media Bengkulu dan koran Nasional (4) Ketidak pahaman pengiklan mengenai referensi, positioning, ukuran-ukuran secara teknis (missal model-model iklan) yang dimiliki oleh Surat Kabar Rakyat Bengkulu, sehingga Surat Kabar Rakyat Bengkulu 
harus mengarahkan terlebih dahulu kepada calon pengiklan.

\section{Evaluasi Terhadap Pelaksanaan aplikasi Strategi Komunikasi Pemasaran Surat Kabar Rakyat Bengkulu dalam Menjaring Pengiklan.}

Evaluasi dalam melakukan bertujuan untuk mengetahui barhasil tidaknya program komunikasi pemasaran. Evaluasi ini dilakukan bersama antara Surat Kabar Rakyat Bengkulu, Bengkulu Ekspress, Radar Bengkulu, Radar Selatan, dan suratkabar lokal lainnya melalui laporan keuangan. Dari laporan tersebut dapat diketahui bagaimana perkembangan yang terjadi (apakah mengalami peningkatan baik yang berkaitan dengan koran maupun pemasaran iklan) dan kadang-kadang apa yang dihadapi serta bagaimana penyelesaiannya.

Jika lebih dicermati lagi Surat Kabar Rakyat Bengkulu sebenarnya bisa melakukan evaluasi yang lebih dalam, dengan menggunakan prinsip $5 \mathrm{~W} 1 \mathrm{H}$, yaitu dengan mengajukan pertanyaan mengapa pengiklan untuk merangsang iklan (khususnya di Harian Surat Kabar Rakyat Bengkulu), darimana mereka mengetahui keberadaan hari ini, dan lain-lain. Memang hal ini cukup sulit, akan tetapi kegunaan evaluasi tersebut untuk mengetahui dan menemukkan motif apa yang mendorong pengiklanan mau bergabung atau bahkan mungkin menjauhi, sehingga dengan pertanyaan tersebut dapat menjawab persoalan-persoalan secara detail.

\section{Langkah- Langkah Surat Kabar Rakyat Bengkulu Dalam Mengatasi Kendala yang Ada.}

Ada beberapa langkah yang dilakukan dalam mengatasi hambatan, diantaranya (1) Melakukan loby-loby khusus dan menyesuaikan dengan target pengiklan.
Hal ini dilakukan dalam upaya untuk menghindari kesalahpahaman pada klien, sebab klien terkadang kurang memahami apa yang dimaksud AE, karena meskipun kalimat yang diterima sama akan tetapi makna yang diterima oleh klien berbeda. Beberapa contoh mencolok adalah kekurangpahaman klien terhadap ukuranukuran iklan secara teknik (model-model iklan). Hal inilah yang mesti dilakukan secara hati-hati dalam memberikan penjelasan kepada klien agar mereka benarbenar dapat memahaminya, sehingga tidak terjadi hal-hal yang tidak diinginkannya, baik itu disengaja maupun tidak disegaja. Contoh tersebut menunjukkan bahwa periklanan merupakan salah satu bentuk komunikasi yang harus terbebas dari adanya kemungkinan yang bisa menyebabkan kesalah pahaman. Oleh karena itu penjelasan pesan sebuah iklan itu sangat penting. Selain itu AE harus juga mengerti/memahami apa klien inginkan, sehingga sasaran-sasaran yang hendak dapat terpenuhi dan menguntungkan klien. Salah satu contoh yang dilakukan AE kepada klien adalah dengan menyakinkan pengiklan bahwa untuk menjual produk agar dapat merasakan kepuasan yang nyata, maka cara yang dilakukan yaitu dengan mengiklankan produk/usaha yang dijalankan. (2). Proaktif, yaitu harus berani menunjukkan dan menyakinkan klien tentang keunggulan produk baik koran maupun iklan. Disamping itu juga harus berani menyakinkan klien bahwa periklanan Surat Kabar mampu menghasilkan suatu "karya" yang kreatif bisa membuat suatu produk lebih menarik dari fakta aslinya.

Ada satu hal yang menarik bahwa usaha meningkatkan penjualan produknya, Surat Kabar Rakyat Bengkulu mengupayakan adanya peragaman iklan lebih inovatif yaitu iklan yang biasanya berbentuk iklan bisnis lebih diarahkan ke iklan advertorial. 
Semua tindakan di atas dimaksudkan untuk menerang perhatian klien yang pada akhirnya akan merubah sikapnya akan merubah sikapnya untuk menggunakan produk/jasa Surat Kabar Rakyat Bengkulu. Langkah-langkah yang dilakukan Surat Kabar Rakyat Bengkulu dalam rangka untuk menjaring pengiklanan sudah cukup bagus, yang mana ia selalu berusaha menciptakan suasana yang dapat membuat pengiklanan akan merasa tertarik dengan produk/jasanya. Disamping itu dengan adanya pemberagaman iklan yang dirancang lebih inovatif, maka tindakan ini mengindikasikan bahwa Surat Kabar Rakyat Bengkulu benarbenar ingin membuktikan keberadaannya sebagai perusahaan yang dapat diandalkan dan siap bersaing di dunia bisnis.

Hal yang harus disadari bahwa setiap produk pasti akan mengalami siklus hidup seperti halnya manusia, yang mana mereka mengalami pertembuhan pada awal kehidupan, dan pada akhirnya akan mengalami kemerosotan.

\section{Analisis Kritis Pelaksanaan Aplikasi Strategi komunikasi Pemasaran Jawa Pos-Surat Kabar Rakyat Bengkulu}

Persaingan yang terjadi dalam dunia bisnis khususnya surat kabar semakin tajam seiring dengan meningkatkan perekonomian. Berbagai usaha dilakukan oleh produsen untuk merebut khalayak dengan cara memanfaatkan iklan. Hal tersebut terbukti dengan banyaknya iklan yang bisa ditemukan diberbagai media, baik cetak maupun elektronik. Alasan itulah yang dapat dikatakan bahwa iklan merupakan bagian dari kehidupan yang terkadang kurang disadari kehadirannya dan belum dikenal oleh masyarakat, maka dapat dirasakan bahwa kandungan iklannya masih sangat sederhana, seolah-olah harian ini hanya sekedar ingin memperkenalkan identitasnya kepada khalayak.
Dalam perkembangannya Surat Kabar Rakyat Bengkulu berusaha untuk menampilkan iklan secara sempurna dalam pengertian format iklannya dibuat lebih bagus dari format sebelumnya. Hal tersebut terbukti bahwa dengan memperbaiki kualitas ternyata mampu menarik perhatian dari khalayak sehingga dapat meningkatkan omset iklan. Namun dalam dunia bisnis khususnya surat kabar, diperlukan sumber daya manusia yang tangguh dalam menjalankan aktivitas perusahaan dengan komunikasi yang baik. Namun dalam dunia bisnis khususnya surat kabar, diperlukan sumber daya manusia yang tangguh dalam menjalankan aktivitas perusahaan dengan komunikasi yang baik.

Komunikasi merupakan kegiatan yang mutlak, sebab dalam komunikasi pemasaran modern, perusahaan harus dapat berkomunikasi dengan pelanggan potensial. Bentuk komunikasi antara produsen dengan konsumen dapat dilakukan dengan berbagai cara. Setiap tindakan perusahaan harus dapat dilihat sebagai elemen komunikasi dari keseluruhan kegiatan komunikasi perusahaan. Namun demikian kegiatan komunikasi perusahaan yang utama adalah melalui periklanan yang memiliki daya komunikasi yang kuat dan merupakan alat komunikasi yang membantu menjual barang/jasa, serta ide-ide melalui saluransaluran informasi dan promosi. Periklanan juga mampu meningkatkan penjualan sebagai ujung tombok pemasaran, karena iklan dipandang lebih efektif dan mampu mempengaruhi khalayak.

Aplikasi strategi tersebut dapat dimanfaatkan perusahaan dalam mencapai tujuan pemasarannya, yang mana dengan adanya jaringan distribusi dapat membantu dalam meningkatkan oplah penjualan serta omset iklan suatu perusahaan. Selain itu pemasaran merupakan usaha sadar untuk mengelola proses pertukaran guna menjamin hasil yang diinginkan, yaitu meliputi 
analisis, perencanaan, pelaksanaan dan pengendalian program yang telah dirancang untuk menciptakan, membentuk, mempertahankan pertukaran yang menguntungkan dengan pasar sasaran demi tercapainya sasaran organisasi (Kotler, 1986 :37). Jadi pemasaran perlu memahami selera/keinginan konsumen karena setiap permintaan terkadang berbeda dengan keinginan perusahaan. Dengan mengetahui keinginan serta kebutuhan konsumen perusahaan diharapkan mampu melakukan dan memberikan pelayanan terbaik.

Bagi suatu perusahaan istilah persaingan bukanlah hal ini dapat dirasakan bahwa setiap perusahaan (apalagi dengan perusahaan yang sejenis) tertentu terjadi banyak persaingan. Selain itu dengan semakin banyaknya sumber alternatif dalam mendapatkan informasi seperti televisi, internet, buku, maka hal tersebut dijadikan antisipasi Surat Kabar Rakyat Bengkulu agar lebih meningkatkan mutu produknya, baik informasi maupun iklan sehingga khlayak tetap menaruh minat pada Harian ini.

\section{PENUTUP}

\section{Kesimpulan}

Pada dasarnya setiap perusahaan (dalam hal ini Surat Kabar Rakyat Bengkulu) membutuhkan mengaplikasian strategi komunikasi pemasaran dalam visi dan misi perusahaan secara lebih efektif. Tanpa adanya aplikasi strategi komunikasi pemasaran, kemungkinan besar perusahaan tidak akan menjalankan. Oleh karena itu dengan adanya aplikasi strategi komunikasi pemasaran, dapat membantu perusahaan dalam meningkatkan pendapatan guna mempertahankan kelangsungan hidupnya. Surat Kabar Rakyat Bengkulu melakukan aplikasi komunikasi pemasaran dengan cara periklanan, penjualan langsung, pensponsoran, promosi penjualan, pameran, tenaga penjualan, seminar, serta strategi penetrasi pasar. Disamping itu, Surat Kabar Rakyat Bengkulu juga memanfaatkan seluruh saluran atau media untuk meriklan seperti radio, spanduk, stiker, poster (outdoor).

\section{Saran}

Surat Kabar Harian Rakyat Bengkulu perlu melakukan perbaikan dalam melaksanakan stretegi komunikasi pemasaran untuk menarik konsumen mengingat banyaknya persaingan kedepan. Hal ini yang perlu direnungkan untuk lebih meningkatkan strategi komunikasi pemasarannya agar lebih menyakinkan konsumen tentang keberadaan Surat Kabar Rakyat Bengkulu.

\section{DAFTAR PUSTAKA}

Angipora, Marius. P. 1999. Dasar-dasar Pemasaran. PT Raja Grafindo Persada. Jakarta

Assauri, Sofjan. 1999. Manajemen pemasaran: dasar, konsep dan strategi. PT. Raja Grafindo Persada. Jakarta

DE Dossier, M.Wayne. 1976. The Marketing Communication Proses. Tokio,McGraw-Hill Kogakussha, Ltd. Japan

Djaslim, Saladin.1991. Unsur-unsur inti pemasaran dan manajeman pemasaran. PT Remaa Rosdakarya. Bandung

Djuroto, Totok. 1995. Manajemen Pers.. PT Remaja Rosdakarya. Bandung

Effendi. U. onong .1993. Dinamika Komunikasi. PT Remaja Rosdakarya. Bandung 
I.G.N.Putra 1996. Periklanan.Penerbit Erlangga. Jakarta

Khasali, Rhenald 1995. Manajemen Periklanan (Konsep dan Aplikasinya di Indonesia). Pustaka Utama Grafiti. Jakarta

Kotler/Amstrong. 1992. Dasar-dasar pemasaran.Penerbit Erlangga. Jakarta

Kotler, Philip dan Suseno, AB .2001. Manajemen Pemasaran di Indonesia (Analisa, Perencanaan, Impilakasi dan Pengendalian).Penerbit Salemba Empat. Jakarta

Moleong, J. Lexy. 2000. Metode Penelitian Kuantitatif. Penerbit Remaja Rosdakarya. Bandung

Panuju, Redi. 2001. Komunikasi Organisasi (dari konseptual-teoritis ke empirik).Pustaka Pelajar Yogyakarta.

Paul, Temporal. 2000. Branding In Asia, Creation, Development and Management of Asia Brand For The Global Market. John Wiley \& Son. Singapore

Siregar, Ashadi 2001. Menyingkap Media Penyiaran, Membaca Televisi dan Radio.: Penerbit LP3Y. Yogyakarta
Shimp. A. Terenca .2003. Periklanan Promosi (Aspek Tambahan Komunikasi Terpadu). Penerbit Erlangga. Jakarta

Sk, Ishadi. 1999. Prospek Bisnis Informasi di Indonesia. Penerbit Pustaka Pelajar. Yogyakarta

Staton, William J. 1996. Prinsip Pemasaran. Penerbit Erlangga Jakarta.

Susanto, Astrid, S. 1988. Komunikasi dalam Teori dan praktek. Penerbit Bina Cipta. Bandung

Swasha. Basu DH. 1984. Azaz-azaz Marketing. Penerbit Liberty. Yogyakarta

Swasta, Basu da Handoko, T. Hani. 2000. Manajemen Pemasaran (Analisa Prilaku Consumen). Penerbit BPFEUGM. Yogyakarta

Swasta, Basu dan Irawan. 1990. Manajemen Pemasaran Modern.: Penerbit Liberty. Yogyakarta

Winardi. 1998. Strategi Pemasaran. Penerbit Mandar Maju. Jakarta 